http://dx.doi.org/10.4314/ejotmas.v7i1-2.11

\title{
FEMINISM AND HUMAN RIGHTS IN UTOH-EZEAJUGH'S OUR WIVES HAVE GONE MAD AGAIN AND FEMI OSOFISAN'S YUNGBA-YUNGBA AND THE DANCE CONTEST
}

*Grace Itoro IBANGA, Ph.D.

\begin{abstract}
This paper examines the concept of feminism and human rights as captured in Tracie Utoh-Ezeajugh's Our Wives Have Gone Mad Again and Femi Osofisan's Yungba-Yungba and the Dance Contest. Feminism is a reaction by the womenfolk to societal misrepresentation whereby patriarchy classifies women as docile, passive, men-haters, witches, etc. Feminism is the clamouring of women's rights on the platform of equality of sexes. It is an intellectual or political movement with a driving force for the recognition of the legal claims of women to their rights as are available in their societies; which are predominately enjoyed by men alone. Feminism purposes to investigate the nature of gender inequality. The term "gender" is an aspect of the collective unconscious of a complex human experience. It is an archetypal element that demands rituals, sex, aggression, social status gender affects power and authority. It is unsurprising; therefore, that patriarchy employs power and authority to dominate over women. This is because men believe they are the lords umpiring over the use of woman. And that is why feminism portrays women's and men's social functions, challenges, experience, interest and feminist politics in different fields of study as anthropology and sociology, communication, media studies, psychoanalysis, home economics, literature and education.
\end{abstract}

Keywords: Feminism, Human rights, Sexual objectification, Patriarchy, Womenfolk

\section{Introduction}

The concept of feminism explores several themes as what Gilligan (10) and Herman (4) describe as "discrimination, objectification especially sexual objectification of women, oppression, patriarchy, stereotyping, art, history," etc. By feminism focusing on the theme of

${ }^{*}$ Grace Itoro IBANGA, Ph.D. is of the Department of English, Olabisi Onabanjo University, Ago-Iwoye, Nigeria

Email: grace.ibanga@oouagoiwoye.edu.ng 
discrimination; implies that there is an unfavorable treatment and consideration of an individual female based on the class which a person or groups of person belong to. The term 'discrimination' as depicted by Sargent (167) is said to be disadvantageous treatment or consideration of women. Discrimination provides psychological support for individuals -women living today and a condition for political assessment against unjust practices on women. Feminism postulates that, women as a group are human beings capable of self - definition. This means that there are various types of feminism: right wing, left wing- centrist, socialist, Marxist, transformational, liberal and queer theory which all advocate for the rights of women to be recognised. The queer theory on its own consists of the radical feminism, lesbianism and homosexuality. All these present the different levels of injustices shown to the womenfolk even in the Twenty-first century and beyond.

However, feminism assumes the unifying them for feminists who advocate the cause of women's rights and recognition according to their different tenets. Feminism as put forth by Moi buttresses that it is a sort of political position (204). 'Femaleness' is a matter of biology and "femininity" is a set off culturally defined characteristics. The implication of Moi's proposed definition as portrayed here is such that have a political edge. This means that it is the activities of women and women's unjust treatment of women's issues that warrant the distinction between biological and cultural accepted forms. Moi is soliciting to the extent those terms might be used to describe the real existing usage. The use of phrases like 'external feminine' as posited by Goring et al (195) gives a clearer meaning that other usages, which are outside feminist viewscould render femininity universal, biological rather than from the cultural perspectives. The word 'femalie' is equally employed to stand for culturally acquired feature.

\section{Feminism and Human Rights: A Theoretical Framework}

The evolution of the concept of feminism introduces series of chaos in the epoch of women literature. Many African women like Emecheta refers to herself as a feminist with small letter ' $f$ '(551); while OgundipeLeslie "denies being a feminist or having anything to do with the ideology of feminism" this is because "feminism" she adds "conjures up visions of aggressive women who try to be like men" (543). The issue of feminism was believed to have originated from Mary Wollstonecraft with her publication of a Vindication of the Rights of Woman in 1792 which presents women as an oppressed group irrespective of their class structure. In this feminist manifesto, Wollstonecraft advises women to be "duly prepared by education, to be the companion of men" (Dobie 106). She also posits that women 
should use manipulative tendencies to get what they want. Mary Wollstonecraft uses radical viewpoints to condemn the unjust patriarchal society that refuses to recognize women's political or legal rights. She stands against the patriarchal constructs that deny women employment opportunities. She equally castigates the menfolk that regard women as men's property.

What informs Wollstonecraft to come up with such radical stand that motivate Horace Walpole, for instance, to refer to her as a "hyena in petticoats? (Dobie 106)." It is as a result of Wollstonecraft hard stand on issue which she condemns men's attitude towards proper representation of themselves. But when it comes to women, they have connotative or pejorative views about them. Other writers like Virginia Woolf, who in 1929 published experimental novel: A Room of One's Own. In this book, Woolf interrogates why women do not dominate history as is the case with men. These women writers' have been trying to free women from the shackles of patriarchal domination. But feminist mothers like Simone de Beauvoir, Elaine Showalter, Betty Friedan, Julia Kristeva, Flora Nwapa and a host of other women from the European, American and even African continents have presented women and their experiences. They have focused on women's challenges and the need for patriarchy to change his orientations towards women's desires and conditions.

A close look at the African evolution of feminist consciousness have also shown how the African women, to some extent have continued to represent the aspect of women's oppressions and relegation. The African women have determined overtimes to rewrite themselves, taking the clue from what Wollstonecraft had started. They develop women's history both in social and literary levels. The history as represented by Elaine Showalter is seen where she divides the women's history into three phases, namely: (i) the feminine phase (1840-1880); (ii) the feminist phase (1880-1920); and (iii) the female phase $(1920$ - present). She posits that in the feminine phase, the women writers followed the literary tradition that had been laid down by men. They were very careful not to use polluted language, and they also avoided the use of subject matter that could indict the men folk. They follow religiously history and deny themselves the right to be recognised.

The novelists that dominated this literary period were Charlotte Bronte, Jane Austen and Mary Ann Evans. These novelists wrote using the popular forms and styles acceptable by recognised writers who were all men. Some of them shed off their female identity, and adopted pseudonym so that they could be published as well as be accepted by the larger society. Charlotte Bronte for instance changed her name to Currer Bell, while George Eliot was pseudonym taken by Mary Ann 
Evans. The aim was for them to hide their female authorship. They were thinking more of social acceptability than anything else. If economic consideration was also a driving force, it must have been for them to make ends meet. When we take a look at Feminism and the perspective of "transgenderism", people may think that it is a recent development that is associated with the Twenty-first century. But it has started as far back as 1840 when the above mentioned writers lived in.

The term "transgenderism" is "a state or condition in which a person's identity does not conform unambiguously to conventional ideas of male or female gender" (Transgender/https// en.oxforddictionconaries.com. Transg. 25/03/2018). Web MD advocates that transgender people claim that they were assigned a sex that is not true to who they are. The point they are stating is that "gender does not exist on a continuum." This implies that there are a lot of human beings who are not satisfied about their natural/biological sex, and they proceed to seek for alternative for themselves. The concept of transgenderism is an umbrella term describing whenaperson's gender identity is different than what society expects based on the person's sex. The literary and intellectual transgenderism which Bell and Eliot got involved in the Nineteenth century had been to create opportunities for themselves to display their creative abilities as well as to be read by their public. However, they involved themselves into such act of gender changed to be able to compel the patriarchalestablishments of the English culture to read their works, and to get their creative pieces published. With this in minds, these novelists [George Eliot and Currer Bell] decided to follow the line of pseudonym. It was the pressure of that time which pushed them to take such radical decisions in order to portray themselves and their creativity.

The question we should be askingnowwiththe current use of the word "transgender" is: Are the transgendered participants moved by the society or by their own obnoxious reasons to carry out their intention? This question gets answered when we take few cases of what happened before and after transgenderism. For instance, Bruce Jenner born in 1936 and Eight Hundred and Four cases of transgenderismhave been recordedwho changed from female to male sexes transgender and vice-versa. He went through plastic surgery feminisation. Bruce Jenner was a well-reputed sports person and an Olympics gold medal-winning athlete during the early part of his life. He married a television reality story, keeping up with the Kard Shianus, Jenner decided to transition to a woman. Today she (Cartlyn Jenner) is one of the strongest transwomen alive in the world (googleweblight.com.) There are many other such cases projected in 
history, but the point we are trying to make is that, the woman is always known for her industry. She is dynamic, enterprisingas well as endowed with all the virtues which could bring about thechanges she wants for her society without having to transgender.

Showalter's second-Feminist Phase signifies a stage in which women rebelled against the status quo, and protested their lack of rights, and they worked hard to secure them. In the political terrain, feminists like Susan B. Anthony, Elizabeth Cady Stanton and other prominent ones amongst them struggled to secure equality under the law. Some of the more radical feminists, Betty Friedan, ChandraMohanty, and othersenvisioned separate femalecentered cultures. These were the set of radical feminists that protested against the unjust prediction of womenfolk by the male writers.

The Third Phase of feminism as propagated by Showalter is the Female phase. In this stage, the female experience is projected in art and literature. The implication of this phase is that, the female writers turn to their own lives for subjects. They begin to explore the elegance of expression that had exampled women lives and women's writings. This new phase begins to give way as the "new" woman and her frankness emerge, where women talk and analyse their sexuality without being timid. It also means a stage where the modern woman looks inward into the male with a great effort to reveal what Dobie (107) calls the "misogyny". This is a state wherepatriarchy displays negative attitudes towards women because of their frankness in presenting issues bothering $n$ their lives.

The women writers turn their attention to the examination of their own works to be able to recreate or re-represent the female character in a manner that is of devoid the patriarchal myth of female presentation. In order to accomplish this latest effort, Showalter calls it "gynocriticism" (Showalter 8). Gynocriticism is a movement that ascertains the distinctive characteristicsof the female experience that is contrary to the initial approaches that depicted the women by using patriarchal standards. Having delved a bit into what could be seen as the evolution of feminism, and how the new feminists have turned to themselves as the subject matter of their writing;it is also important to explain that the African women writers get inspiration to create from the Western feminisms. They have taken to this approach on the note that feminism might be determined by the standards of its environment - culture etc. Through the knowledge of feminism, female writers are occupied by propagatingthe interest of women in the patriarchal cultures where they live. Although some of them believe that feminism is only white women centred because it was propounded with Eurocentric concerns. The views of the African women posit that Western 
feminism has only taken into consideration the situations of the white women, tending therefore to ignore other women of colours.

Some white women claim to speak for all women without considering the nature and peculiarsituations of African women and their experiences whom they want to defend. The essence of their decision is based on the fact that Western feminist perspectives, strategies and practices differ from the African belief systems. Besides, Western feminism do not make provisions for certain approaches which are African oriented- polygamous marriage system, steprelationships, African cosmology, etc. In fact, the African women initially rejected the western feminism based on what Ndulue (11) describes as: "... a malignant symptom of a world turned upside down... [The] degeneracy that has afflicted the ethos, norms and mores." A close assessment of this view contradicts with Ruthven's perspective of Western feminism which proposes "to speak for all women many of whom do not want to be spoken for in that way" (33). The new writings by African women adopt the understanding of feminism to involve an evaluation of the claims of its self- identified proponents. By seeking to provide a detailed analysis of the new movement, Walker explains that:

For many of us it seems that to be afeminist in the way that we have seen orunderstood feminism is to conform to an identityandthe way of living that doesn't allow forindividuality, complexity, or less than perfectpersonal histories. We fear that the identitywill dictate and regulate our lives, instantaneouslypitting us against someone, forcing us to chooseinflexible and unchanging sides, female againstfemale, black against white, oppressed againstoppressor, good against bad. This way of orderingthe world is especially difficult for a generation that has grown up transgender, bisexual, interracial, and knowing and loving people who are racist, sexist and otherwise afflicted. (22)

The implication of what Walker is advocating is the critical overview of justifying third-wave feminism to embrace what Synder classifies as: "a multiplicity of identities, accept the messiness of lived contradictions and eschew a unifying agenda; these hall marks make third-wave feminism difficult to define (177)." This means that the new wave feminism is difficult to define because it tends to explain the frustration of the proponent as captured in Synder's claims that: this 
insistence on definition is really frustrating because feminism gets backed into a corner. Peoplekeeping on defining and defining and making a smallerdefinition-and it's just lazy thinking on their part. Feminism is something in individual to each feminist (177).

The third-wave-feminism exhibits some imitations such as what Synder calls: "a youthful myopia, an ignorance of his story, and a sense of self- importance". This implies that this new feminism is still on embryonic state of feminist politics. This motion is further interpreted by Findlen $(6-7,9)$ when she states, "We are the first generation for whom feminism has been entwined in the fabric of our lives, it is natural that many of us are feminists... This country hasn't heard enough from young feminists. We're here, and we have a lot to say about our ideas and hopes and struggles and our place within feminism." Braumgardner equally asserts that the third-wavers are not bemoaning the invisibility of feminism among young women, as was the preoccupation of the second generation feminist mothers. The new way of representing feminism as she portrays is that: "feminism is out there, tucked into our daily acts of righteousness fluoride. We scarcely notice that we have it- it's simply in water." (Synder 178).

The purpose of this paper is not to enlist the characteristics of the different kinds of feminism; instead, it seeks to examine how Tracie Chima Utoh-Ezeajugh and Femi Osofisan have employed the drama genre to propagate the feminist mission of change, as well as stimulate women in the Nigerian society to work for the better future for their female estates. The paper critiques how the playwrights use the technique of "talking-back-syndrome" to replay the new politics in Nigeria. They also highlight the extent to which women have asserted themselves as catalysts of change in their drama pieces. However, Adimora-Ezeigbo and some other African women- Nawal El-Saadawi, Buchi Emecheta, Zoe Wicomb, etc., assert that, feminism is relevant and paramount in fighting the cause of the African women better than other alternatives of African feminism - "Stiwanism", "Womanism", "Motherisim," Femalismetc - which the American based-African women propounded, and yet lack the effectiveness to weld the African women together to achieve their emancipation. But Adimora-Ezeigbo explains further: "To me, the quarrel about terminologies like feminism or womanism does not really arise. What is important is how people demonstrate their beliefs and how they go out helping other women and ensuring that women are emancipated." (Arndt 40).

Adimora-Ezeigbo is a feminist but not in the radical western term. She desires that women should be liberated, not to sit on men's head. She insists that women should be liberated to continue their lives as people that have psychological, intellectual, political and economic freedom of what it takes to be free. Adimora -Ezeigbo wraps all these 
up in the conversion she had with Susan Arndt on December $12^{\text {th }}$, 1995. "I disagree that we need a new nomenclature for feminism in Africa. There is nothing wrong with the term 'feminism.' I don't think the term 'Stiwanism' is suitable and it cannot replace the other." The implication of what Adimora-Ezeigbo is projecting here is that, there exist the African feminism which has the potentials to solve the inherent problems in the African way.

\section{Recreating Women Rights and Empowerment- An Analysis Domestics and Social Context}

Having stated the relevance of feminism to the African Women empowerment, we want to venture into how the playwrights (UtohEzeajugh and Osofisan) have empowered the new women through their drama pieces. Utoh-Ezeajugh's text challenges the patriarchal myth of the African men. She shows the inherent danger of patriarchal interpretation, where men folk assume the right to represent women negatively. Utoh-Ezeajugh's women come out as vibrant, vocal, political oriented individuals, powerful elegance and immersed in independent professions. African culture is a society where men assume so much power and influence that they do not desire women or their daughters to triumph in the areas bothering on economic and politics. The play Our Wives Have Gone Mad Again (2013) being a feminist drama presents the characters that as Utoh-Ezeajugh put it; "...Ninob with the pulse of real life. She depicts the imminent political realities with the understanding of human nature. Utoh-Ezeajugh uses the play as a "Writing-back-syndrome" to capture the world of men in their relationship with women in social, domestics, economic and even political aspects of their daily lives. She captures on stage a typical instance of domestic affairs between Inyang and Ene his wife:

INYANG: (straightens up) what? Madam EneYou have come. Welcome, Madam Funmi and Madam Mairo welcome...

ENE: (Stand offish) Welcome yourself, foolish man (pointing) Look atthe clock. Is this the time your malesclean the house? Lazy idiot: (Ene expresses her disgust and then marches to a settee.As the other ...(Utoh - Ezeajugh, 22-23).

The woman is now enjoying the privilege and position of authority she finds herself. Ene up turns the hand of the clock against her unfortunate husband, Inyang who she marries with her own property. She states that: 
ENE: Necessary or not, evil is evil and I, Ene, will not put up withit any longer. What have I not done for this useless Inyang? I took him to my village and gave him money to pay my dowry, I sponsored the traditional marriage and the church wedding, I feed this man, I clothe him and I put a comfortable shelter over his head. Now, what do I get in return: ingratitude', He is Lazy,insubordinate and good for nothing, He cannot even impregnate me.Three years since our and nothing has happened. What am I supposed to do with a eunuch? Utoh - Ezeajugh. (24)

The new woman reiterates all the evils that the married men have been exhibiting to their wives on routine basis. "Men are necessary evils or so they say". Funmi, Madam's friend admonishes her as a way of bringing palliative to Ene's 'heart'. This implies that despite their powerful presence felt in the socio-economic context, Mairo and Funmi still express sympathy and concern for the head of the family who has all God's or nature's, mandate to be in control: "And God said, let us make man in our own image, after our likeness and let their have dominion over [all]..." (Genesis 1:26). This means that, through the new women have assumed wealth, power and prestige, they should work hard on their newly acquired image to recognize cadre of nature for "them to have dominion".

MAIRO: Take him to the hospital so that he will be subjectedto extensive medical tests may be he contacted an infection whichdestroyed his reproductive organ. You know how it is, with thesemen from the gutter. (Utoh - Ezeajugh, 24).

Utoh-Ezeajugh believes that if women fully take over the social and domestic affairs of their husbands, there is hope to improve upon their health/medical conditions. She without gloss depicts the scenario of the feminist society to be blatantly advocatingmeaninglessnessof patriarchy its aggressive and destructive traits:

ENE: Which hospital have I not taken him to? Do you know how much thateunuch hascost me in medical bills... Inyang, how long does it take you to walk to my fridge and bring the drinks I bought with money?...Do you want to cause an epidemic in house? (Utoh - Ezeajugh 24-25).

The new matriarchal society as represented by Madam Ene is very surprisingly sophisticated. She comes out as, the cultural Institute 
of female-husband who tries to make (her) influence and wealth feltby the menfolk. Utoh-Ezeajugh also recreates the woman that assumes the position ofa judge to give to the men the cup of vengeance, which initially had been what they had measure water for women. The point I am making here is that, the new woman feels it is proper to reduce the man's status to that of a fulltime-house-husband. He takes care of domestics-washing, cleaning, cooking and shopping for the home. Ezeajugh feels fine to alienate female characters that questionthe man's place at home. Inyang, Madam Ene's husband, for instance is "... from the gutter". She isvery happy confronting him as: "an idiot", "useless", "eunuch". Etc. (Utoh-Ezeajugh, 24).

The man is also accused of impotence:"... he cannot even impregnate me..." (24).

When the patriarchy from time immemorial has been accusing womenofbarrenness, he has notknown that someday, he too would be "...a eunuch". The playwright enlightens the patriarchalsociety on the value of the golden law: "Do to others, what you want them to do to you". It is onthis platform that she allows her female characters to show injustices to their husbands.

ENE: $\quad$ How much did I give you to take to the market?

INYANG: Five Thousand naira.

ENE: So, did you cook one port of soup with five thousand naira?

INYANG: No, I did not buy only soup things, I join many things we need... sorryMadam Ene, I noticed that many things have finished in this house and you need to see how the price of food things are just going up. (Utoh - Ezeajugh, 34-35).

Utoh - Ezeajugh by presenting women who are the bread winners of their families is projecting hard work and perseverance among them. She emphasizes that such women overshadow their husbands, so much that the husbands lost their own right of place, their names and also come to be known by the identities and possessions of their wives, Amazingly, Utoh - Ezeajugh transfers the stereotypical roles which patriarchy often always associate with women in their myth back to them. Inyang, Madam Ene's husband is not only represented as a house cleaner $(22,25)$ a cook $(25,34-35)$ a driver $(33)$, but "...a worthless good - for - nothing" (26) "... a blabbering ...fool” (25) and idle gutter snipe. Madam Ifeoma, another female character in Our Wives Have Gone Mad Again, continue the trend of the image misrepresentation of patriarchy. She has just entered into the sitting room where Madams Mairo, Funmi and Ene are still enjoying the show of ridiculing Inyang; 
She explains the extent to which her "monster husband, locked the door and beat [her] to an unconscious state!", (Utoh - Ezeajugh, 28) to the extent that her neighbours could not rescue her.

Utoh-Ezeajugh uses Ifeoma to portray the patriarchal violence that is executed on the women. The essence is to wash off sympathy and emotions from the mind of the audience wheneverwomen"writeback" to take revenge of such oppressive violence.

IFEOMA ... I went to his office and caught him red handed with a girl. I went wild, beat up the girl and stripped her naked, then I descended on him and would have strippedhim, too, if not that he made a dash for the door anddisappeared ... I went home and waited for him. When he came back, he was so full of apologies that Ibelieved him and was even prepared to forgive him. No sooner had I let down my guard and entered the kitchen toprepare food for him, then he came after melockedthe kitchen door and descended on me. I did not stand a chance (Utoh - Ezeajugh, 29).

Utoh-Ezeajugh searches into the real essence of men's infidelity. Ifeoma being avery beautiful woman does not see any essence on why Zeus should bring disgrace upon her by having an extra marital affair with a girl in his office. She herself refuses to adapt the highly cultured-manner of the liberal African woman. She exhibits a radical approach tohumiliate her husband in the public. If there is any nonsense an African husband cannot take with grain of salt, from his wife is a disgrace of his sexual explorations in the public. To show to his wife, Ifeoma, that he Zeus has been highly embarrassed, he takes to battering his wife without making interference for external mercy. It is true that Utoh-Ezeajugh is not interested in seeking and achieving the current ideology of the complementarity which Adimora-Ezeigbo, Acholonu, etc., are advocating. The feminist ideology of complementarity as posited by Adimora-Ezeigbo (2005) is seen as something that "does not exist but must be gained."However, since complementarity is a necessity based on men's and women's equality in rights and status, Adimora-Ezeigbo believes that a transformation of the existing gender relationship must inevitably come first (Arndt, 42).

Utoh-Ezeajugh is advocating that men and women operating in the radical set of feminism do not have the patience and a cordial relationship that can harbor peaceful and harmonious home. It is the evidence why the women are antagonistic with the men. In the entire play, the women do not yearn for or desire to have babies of their 
own, except where Madam Ene refers to her husband's inability to impregnate her as a way of derogating the man. This is not a good virtue, neither is it a healthy one, rather it is a means to slight on Inyang as a "fool" whom she picks up from the "gutter" to reform. Utoh-Ezeajugh's type of feminism is what Thompson (7) calls "academic feminism" By academic feminism it means works "which either ignores feminism's central problematic of opposition on to male supremacy....... and opposition to male domination, and its concomitant struggle for a human status for women in connection with women, which is at one's expense and which is outside male definition and control".

Utoh -Ezeajugh portrays the value of female socio -economic hence in the consciousness of radical setting:

ENE: Go and lock him up in the police station!

The women believe the time has come for them to take their pound of flesh. They employ the use of the law enforcement service to checkmate patriarchy. Ifeoma, the victim of wife battery and violent attacks, doubts whether making official report to the police can be a solution to her present predicament. The reason to this is not far fetch, it is perhaps, since the law enforcement is dominated by male staff, how is Ifeoma sure that Zeus would be prosecuted? But Ene comes up with a more violence oriented formula.

ENE: Next time your husband picks a quarrel with you, makesure you teach him a bitter lesson, keep a weapon handy. You can put the weapon in a corner of the house where youcan easily reach it, that big pestle your house girl uses to pound yam can serve the purpose.When he makes a move towardsyou, drawhim towards your weapon. Take the weapon and deal him a deadly blow at the back of the head. If you hit him hard enough, he will pass out. When he recovers he will think twice next time the devil pushes him towards self - destruction (UtohEzeajugh 31-32).

This counsel by the radical feminist movement that responding violence to violence has been adequately treated by The New Feminist ... Have Women Ever Reality Had Their Rights when it is point out that:

Today, it has become clear that in NO

HUMAN DEVISED SOCIETY has women 


\begin{abstract}
ever had a clearconception of what their role should be. They do not know who they are, what they are, where they are going.Women have often been victims of their society,unable to find fulfillment and real success in life... And now, $\quad m$ a $n$ women are angry. Some have united to form a vocal minority called the Women Liberation Movement. (Ambassador College Researcher Department 9)
\end{abstract}

Utoh-Ezeajugh states that the new feminists have formed themselves into what The New Feminist ... call "an ultimate goal". The essence is for them to effect changes in every aspect of what is considered a male-dominated society. A clear way to actually carry out this objective is what informs the statement:

FUNMI: If you try that method and it does not work, hire thugs to give him the beating of his life (Utoh Ezeajugh, 32).

The implication ofFunmi's suggestion is that since patriarchy has refused to accept reasoningand friendly dialoguing as a way to give women their rights, they should use violence and elimination method to get what they want. Of course, by suggesting the approach of "pestle"and "thugs" as tools to get Zeus to give Ifeoma her rights; it means therefore Utoh - Ezeajugh has advised the new feminist to prepare for what Feminist Rights...... call"a total revolution" in the entire social structure. Ifeoma does not waste her colleagues counsel,she employs it at an immediate available time and "picks up a pestle and delivers him a deadly blow on the head. Zeus slumps and passes out" (Utoh-Ezeajugh, 57).

Utoh-Ezeajugh borrows the ideology of Adiechie (10) that in the primitive era, which physical strength was a vital attribute for human survival, and since men were generally stronger than women, they were accorded the right to lead. But today, there are many exceptions to this notion of physical strength. In recent times, the vast world of knowledge, technology, science and social media have replaced the earlier notion. Today's leadership is determined not by physical strength any more, but by intelligent, innovative, creativity etc. It is such intelligence and creativity that empower Ifeoma to devise a way of defending herself against Zeus's violence. 


\section{The Political Context}

Utoh - Ezeajugh employs the militant nature for the new radical feminists to talk -back to the political stalwart of their society. She empowers the female politician -Madams Mairo Irene, Funmi and Ene- to display politics the way men know it. They all accept to meet at a certain obscured restaurant to rehearse on Madam Irene political ambition as supporters for their party.

FUNMI: Let us start out deliberations right away. We are here to map out strategies on how to mobilize massive support for our presidential candidate Chief (Mrs.) Irene.... The party primaries will be conducted in threemonths' time. What strategies do we adopt? (Utoh - Ezeajugh 42).

Utoh-Ezeajugh understands the political workings of men,that they always wieldthe emotions and reasoning of their members to support them through captivating speeches as the type put forth by Funmi. Madam Mairo makes her fellow women to realize that Nigerian politics is all about Godfatherism, She registers!

MAIRO: Politics without money is equivalent to child's play. Every position has its price. The highest bidder wins. There is no sentiment about this. With the right amount of money, we can buythe presidential ticket. I have contacted my network of powerful friends. I am happy to inform you that a former mate has volunteeredto make a private donation of one hundred and thirty million naira..... She wants Chief Irene to donate that money to the party, as anincentive. The first Lady has also promised to give the same amount on the eve of the party primaries for on -the -spot negotiation withdelegates. (Utoh-Ezeajugh, $42-43$ ).

The new feminists recognize thefact that networking is an important tool that helps men to succeed in their political career. And they do not want to take chance in their political ambition. These women surround their political campaign manifesto by employing the services of the law enforcement agents, thugs etc. to protect themselves against their opponents when Chief (Mrs.) Irene gives her speech.A lot of people always use the campaign period as a moment to make their opponentsto pay for whatever grudges they would have had with them. Most politicians causeuntold damages to other people's property, arsons to fellow politicians, assassins and thugs to trail their where about etc. And it is because women have always been witnesses to all 
these atrocities but from a distance. It is now time for the woman politicians to put forward their presidential candidate in the person of Chief (Mrs.)Irene Okpirioe - Sabio; so Funmi in conjunction with other women in the group hired Rosandra the bar attendance and twelve unidentified assassins, and assign the photographs of the victim to be eliminated. The girls are commanded by:

FUNMI: We will just go ahead and define your duties ...here are the photographs of your targets Assign each girl to a man. The girls are to work handin hand with our photographer and camera man....in these sheets, you will find details of the social life of your targets their schedule, movement and other relevant details. The girls are to track them down, seduced themand get them into compromising positions... Here are wraps of cocaine. Plant these in the rooms of those sametargets, notify us as soon as you have done this and your job is done ... (Utoh - Ezeajugh, 62).

Utoh-Ezeajugh is asking a significant question regarding Nigerian politics. Why isit ado ordie affair?Why are the politicians so deadly, experimenting on eliminationsyndrome?All the evils that Nigerian male political stalwarts engage in are the samepractices the female have adhered to. No wonder Easton confirms that "political system is the way that societies make decisions about their most important values" or put differently, political system is simply "the authoritative allocation ofvalues" for a society. To the generations of African/Nigerian politicians, it is whatthey want that they press hard to achieve- their political ambition, irrespective of the nature andeven the means of getting it. In Yungba-Yungba and the Dance Context (1993) Osofisan portrays that if the womenfolk are united, and they are also patience enough to wait they could regain all what they had lost, and above all their rights would be given to them. There was a long political tradition being observed in the past as Ayoka posits:

AYOKA: That's how it used to be my friends; in the past, any of ushers could be the priestess; it was never the birthright of a single woman it was a personal legacy of any one,to be passed down the family line, No; it was always won at an opencompetition, the reward of merit; And that is what we nsist it must be again or what do you say? (Osofisan 26)

Osofisan is presenting a political conflict which exists in the religious YungbaYungba festival where the women appear once a year 
"to display your dancing prowess before the men, and choose your husband's (23). But all of a sudden, the rest of the women group discovers that:

DUNBARIN: Iyeneri is a usurper; she has been running theshrine illegally, beyond the limits is of the authority first granted to her and purely according to her whims. For yearsshe has been exploiting our ignorance, and ourgenerosity, and our difference; if the festival must continue, then lyeneri must step down now! She must surrender her powers. (Osofisan 22)

Osofisan is claiming that the concept of power tussle is not a recent phenomenon in the feminist circle. The women had been political priestesses long before civilization. The mothers were adopting open or public policies where all their decisions making or taking had always involved all women. But since lyeneri usurps power of authority, she resists the participation of others:

AYOKA: Our fore mothers! Let's give praises to these ancestorswho love so often to malign! You know, our fore mothers who started this festival, they loved their fun, but they werealso thinking women, and they decided to mingle their fun withtheir other serious needs!!! As our mothers danced, so did they alsoremember the welfare of their community. As they sang their songs, so did they keep in mind their responsibility to others and to themselves ...? (Osofisan 24)

Osofisan uses Ayoka to point out what the past political leaders were interested in "... to find two women to represent them every year, in the assembly of the Baale...." She states that the older women had their representative-lyaloja in the seat of power. But with the new regime, the youthsor younger women do not have a voice. She points out that political foremothers were muchenlightened, than the new feminist politicians. And that except the voices of the old and young blend together, that harmony might not come to the land.The African women are not seeking for ways where they could replace one relegation or separatism or oppression withno other; instead, they yearn for a free for all society where their rights are given to them to develop their political potentials. They are striving to overcome and perhaps reject artificial hindrances that keep them on disadvantage. For Osofisan, unlike Utoh-Ezeajugh he inculcates in his female characters to look for a stable society recognized through the corporate endeavor 
of sexes. The women try to reunite the world by building their positive roles in the areas where theircontributions could yield effective results for both sexes. ButUtoh - Ezeajugh advocates aretaliation - syndrome of teeth - for tatath. Even when it involves lyeneri, a fellow woman like them, they react against her greedy syndrome which robs her from carrying other women along.

IYENERI: a fellow woman like them, they reacted against her greedy syndrome which robs her from carrying other women along.

AYOKA: That is wha what we want! What we demand for several years now, against therules our tradition, lyeneri, greedily and selfishly soaking herself in its privileges, our mother to accept to live with corruption, but we must not be negotiated, Iyeneri must step down now, this season! (Osofisan 26)

The playwright is insisting that the new women should ".... reclaim [their] rights; re-establish the principles of merit and of free choice!" He portrays that let the competition of selecting and installing a new political priestess be a culminating efforts: "the practice used to be and hence as our representative in the Baale's Council! Ayoka declares." (Osofisan 26). Osofisan preaches the message of oneness among the sexes. It does not matter if they women should sacrifice their dancing skill, their youth and their suppleness, but that there is hope:

AYOKA: But we recover our rights in the end, don't we?Freedom, the right to have ourown voices heard. What, my friends, could be greater than that? To be able tocarry our grievances with our own mouthsstraight to the ears of power.... My sisters,weighty things are happening in the land. The world is moving, and rapidly too, allaround us nothing stand still! Except us!Are we youths just going to continue todance gleefully every season and choose our husbands, as of that's all were good for?The affairs of our state, don't they concern us too? (Osofisan, 29).

Osofisanempowers Ayoka, the women's spoke person to enlighten the women that times have changed. The global women are no longer depending upon their husbands (men) to place food on their tables, to bring about the market control price, to find solution to diseases ravaging among their older parents, etc, instead, let all the women join their voices together and insist on being heard!

While Osofisan is soliciting for women to fellow their course of liberation through negotiation, dialoguing and peaceful approach; Utoh - Ezeajugh insists that women should give violence - for -violence to 
patriarchy to be able to with their mandate. For instance, Ifeoma retaliatesZeus's violence to her by hitting him with a pestle and he slumps and passed out.Again the society does not want to hear that it is a woman that shows violence on a man, but instead itprefers it to be the other way around.

Furthermore, on the day of Chief Irene's campaign, the patriarchal society accuses the female presidential candidate of causing death to her opponents. The crowd, majority men bring up so many oppositions on why it should be the woman that is at the fore font of Nigerian politics.

5TH MAN: Rumours are rife that some of your former opponents, in fact, four of them died within the space of two weeks under very ways mysterious circumstance, how true is this?(Utoh-Ezeajugh 78)

Utoh-Ezeajugh projects that it was in the past that the African women in patriarchal- authored works wereas shown in the negative lightwith all pejorative tendencies. But she presents the modern women as bold, daring, resilient, with very rich retentive memory, they are full of intelligence, and above all, they are influential. The people choice, LPP presidential candidate explains:

IRENE: Death is inevitable. We live with this knowledge every day of our lives!!!My enemies and detractors are at work; pay no attention to them... This country is ripe for awoman president. I have come to right the wrongs that have been perpetuated against each and every one of you. If you give me your votes, I will build all you roads. I will install electricity and pie borne water everywhere; I will initiate a welfare scheme for unemployed husbands. I will build homes for orphans.... (Utoh - Ezeajugh 79-80)

Irene is Utoh-Ezeajugh's rejuvenated African woman-voice-ofconscience. She is reminding the men group of the singular fact that, they should watch them in- and- out actions. Patriarchy is admonished to mind the kind of fake promises he makes to the people when the menfolk are thirsty for power.She claims that of all the political regimes - past and presents - Africans leaders impose themselves upon the populace, none has ever fulfilled his campaign promises. Some of them live as if they would not appear before their Creator to give an account of their stewardship (Ecclesiastes 12:14; 11Corinthians $5: 10)$. The presidential aspirant goes ahead to re-represent a popular ministry created duringObasanjo's first regime between 1993- 2001 Better life for Rural Women Support Programme which only existed 
then to generate millions of Naira for the people in power. Irene informs the people that besides all other promises;

IRENE: Oh I have great plans, I will create a ministry for men affairs under which theycan run such programmes as: Better Life for Rural Men, Husband Support Programme and many lucrative.... Sorry I mean expedient programmes.(Utoh-Ezeajugh 77)

Utoh-Ezeajugh defies the notion that silence is not a virtue for African females. She negates Okereke's (133) views, "vocality is a male prerogative and silence a female virtue" by creating female character express their views eloquently. She deploys language as decorum for expressing female mandates. It also gives them the audacity to return all the negative venoms of phrases and abusive words to their opponents- male in a "Talking - Back" syndrome. She imbues in women the ability to create their own identities.

\section{Conclusion}

Utoh-Ezeajugh's Our Wives Have Mad Again has deconstructed the dominant female characters in African culture. She achieves this by creating space and independence for women in African culture. UtohEzeajugh reinvents the African female character to reflect the concept of new era in politics she creates new politics. She assumes new perspectives for the women to reposition themselves towards total emancipation. She redefines the notion of complementarity, to includegiving back to patriarchy the negative attitudes he has imputed in the female sex over time. She is strongly against cordial relationship amongst both sexes, and perhaps could explain why the women are always antagonistic with the men- husbands. Besides, the playwright does not give the characters the privilege to make babies. Osofisan's Yungba-Yungba and the Dance Context reminds African woman that times have changed. If they want to achieve their rights, there must be a repositioning of their aims and vision. Osofisan believes strongly in the concept of complementarity of men and women living together in love, peace and harmony as a means of achieving their total emancipation in a free and fair society. 


\section{Works Cited}

Adimora-Ezeigbo, Akachi. Interview with Chukes Oluigbo. Web. 29 July $2019<$ http.//www. Africawriter.com/categories/profiles-\&interviews.2005>.

Arndt, Susan. "Paradigms of Intextuality, Orature and Writing Back." Ed. Patrick Oloko. The Fiction of Akachi Adimora-Ezeigbo: Issues and Perspectives. Lagos: African Cultural Institute, 2008. 17-65. Print.

Chodorow, Nancy J. Feminism and Psychoanalytic Theory. Yale: University Press, 1991. Print.

Dobie, Ann B. Theory into Practice: An Introduction to Literary Criticism. Ed. Easton David. The Political System: An Iniquity into the State of Political Science (2th ed.). New York: Alfred A. Knopf, 1971.Print.

Findlen, Barbara. "Introduction from Listen Up: Voices from the Next Feminist Generation." Ed.

Gilligan, Carol. "In a Different Voice: Women's Conceptions of Self and Morality." Harvard Educational Review, 1977. Print.

The Holy Bible. Authorized King James. Michigan: Zondervan, 2000. Print.

Joseph, Yakubu. "Problems of Women Writers." A. M. News, October 30, 1995:5. Print.

Lerman, Hannah. Feminist Ethics in Psychotherapy. Cham: Springer Publishing Company, 1990. Print.

Lesile Heywood. An Encyclopedia of Third Wave Feminism Vol.1, A-Z. West Port, CT: Greenwood, 2006.5-6. Print.

Ndulue, Erasmus. "The Futility of Feminism." Sunday Guardian. Lagos: Guardian Press, April 28, 1996. Print.

The New Feminist .... Have Women Ever Really Had their Rights, California: Ambassador College Press. 1970 (Ambassador College Research Department).

Osofisan, Femi. Yungba-Yungba and the Dance Contest. Ibadan; Heinemann Educational Publishers, 1993. Print.

Ruthven, K. K. Feminist Literary Studies. Cambridge: Cambridge University Press, 1984. Print. Schermer, Victor L. "Commentary: The Complexity of Gender." Gender Issues in Group Therapy 32.1 (2008):57-70. Print.

Showalter, Elaine (Ed.) The New Feminist Criticism: Essays on Women Literature and Theory. New York: Pantheon, 1985. 1-12. Print.

Synder, Claire R. "What is Third-Wave Feminism? A New Directions Essay." Signs 34.1(2008): 175-196. Print. 
Transgender/https//en.oxford.dictionaries.com.transg. Web. 25 March 2018.

Utoh-Ezeajugh, Tracie C. Our Wives Have Gone Mad Again and other Plays. Lagos: Valid Publishing Company, 2001. Print.

Walker, Rebecca. "Being Real: An Introduction." Ed. Lesile Heywood. To Be Real: Telling the

Truth and Changing the Face of Feminism. Minneapolis: University of Minnesota Press, 2006. 19-23. Print.

Wollstonecraft, Mary. A Vindication of the Rights of Woman. London: Penguin Books, 2006. Print. Wordsworth: Cengage Learning. 2009:104-130. 